\title{
Development of an Enzyme Immunoassay for Serum 16-Dehydropregnenolone
}

\author{
Noriko TAgawa, ${ }^{a}$ Kayoko SAIKI, ${ }^{b}$ and Yoshiharu KobaYaShi ${ }^{*}, a$ \\ Clinical Chemistry Laboratory, ${ }^{a}$ and Central Analytical Laboratory, ${ }^{b}$ Kobe Pharmaceutical University, 4-19-1 \\ Motoyamakita-machi, Higashinada-ku, Kobe 658-8558, Japan. Received April 5, 2001; accepted May 28, 2001
}

\begin{abstract}
We have developed an enzyme immunoassay (EIA) for serum 16-dehydropregnenolone (3 $\beta$-hydroxy-5,16pregnadien-20-one; 16-DHP). The antiserum against 16-DHP-3-hemisuccinate conjugated bovine serum albumin (16-DHP-3HS-BSA) was raised in rabbits. For use as an enzyme labeled antigen, 16-DHP-3HS was conjugated to alkaline phosphatase. The minimal amount of 16-DHP detected was $4 \mathrm{pg}(0.013 \mathrm{pmol}) /$ assay and the measurable range was from $0.06-60 \mathrm{ng} / \mathrm{ml}(0.191-191 \mathrm{nmol} / \mathrm{l})$. The intra-assay coefficient of variation (C.V.) was $4.1 \%$ $(0.73 \pm 0.03 \mathrm{ng} / \mathrm{ml}$, mean \pm S.D., $n=6)$, and inter-assay C.V. was $7.7 \%(0.13 \pm 0.01 \mathrm{ng} / \mathrm{ml}, n=6)$. A liner relation was observed between the serum sample dilution and the 16-DHP concentration. For the recovery study, authentic 16-DHP was added to a serum sample (original concentration: $0.10-0.14 \mathrm{ng} / \mathrm{ml}$ ), and the recovery was found to be $94.4-96.8 \%$ (final 16-DHP concentrations calculated: $0.29-16.3 \mathrm{ng} / \mathrm{ml}$ ). To investigate the reliability of the present EIA, the values from our EIA were compared with those obtained by GC-MS. The 16-DHP concentration could not be measured in serum by GC-MS because of its sensitivity. Therefore, the conjugated steroid, 16DHPS, was first enzymatically hydrolysed and then the 16-DHP measured by both methods. There was a good correlation between the levels determined by these methods (Pearson's correlation coefficient: $r=0.927$, $p<0.001, y=0.74 x+3.61, n=27$ ). The serum concentrations of 16 -DHP in neonates and umbilical vein were $0.53 \pm 0.09 \mathrm{ng} / \mathrm{ml}$ and $0.88 \pm 0.61 \mathrm{ng} / \mathrm{ml}$, respectively. No 16-DHP was detected in serum from normal healthy adults using the present EIA. These results suggest that 16-DHP originates from the fetus and neonate.
\end{abstract}

Key words 16-dehydropregnenolone; EIA; serum level; neonate, cord serum

Pregnenolone ( $3 \beta$-hydroxy-5-pregnen-20-one) is the key metabolite in steroid hormone biosynthesis, and is the source of the various steroid hormones. Among these numerous metabolites of pregnenolone, 16-dehydropregnenolone (3 $\beta$-hydroxy-5, 16-pregnadien-20-one, 16-DHP) has a very unique structure with a double bond present between the C16 and 17 positions of the steroid skeleton. Although the enzyme(s) which catalyze the formation of the double bond at C-16 have not been identified in human, Kwan et al. ${ }^{1)}$ have demonstrated that 17 -hydroxypregnenolone $(3 \beta, 17$-dihydroxy-5-pregnen-20-one) was metabolized to 16-DHP by neonatal porcine microsomes. Watkins et al. ${ }^{2)}$ also reported that the conversion of $16 \alpha$-hydroxyprogesterone $(16 \alpha$ hydroxy-4-pregnene-3,20-dione) to 16-dehydroprogesterone (4,16-pregnadiene-3,20-dione) was observed in the presence of 16-dehydroprogesterone reductase obtained from cell extracts of the intestinal anaerobe, Eubacterium sp. strain 144.

16-DHP was initially identified in the mono-sulfate conjugate fraction of neonatal feces by Gustafsson et al. ${ }^{3)}$ Subsequently, this steroid has been identified in human placenta, ${ }^{4)}$ urine, ${ }^{5-8)}$ gall-bladder bile, ${ }^{9)}$ meconium ${ }^{10}$ and amniotic fluid. ${ }^{11)}$

Previously we also identified 16-DHP in the serum of immature infants and we suggested that it is a form of the sulfate conjugate, 16-DHP sulfate (16DHPS). ${ }^{12,13)}$ Moreover, we have confirmed that 16-DHPS originates from the fetus and neonate, and this led us to speculate on the existence of a pregnenolone sulfate $\rightarrow 16$-hydroxypregnenolone ( $3 \beta, 16 \alpha$-dihydroxy-5-pregnen-20-one) 3 -sulfate $\rightarrow 16$-DHPS pathway, in the fetus. ${ }^{14)}$ However, due to the low levels of 16-DHP, in human circulation little is known about this unconjugated form.

In the present study, we newly developed a sensitive enzyme immunoassay (EIA) for the detection of 16-DHP, and used it to ascertain the existence of this steroid and to measure its concentration in fetal and neonatal blood.

\section{MATERIALS AND METHODS}

Materials The chemicals used in this study were obtained from the following sources: 16-DHP (Steraloids Inc., Newport, RI, U.S.A.); 1-ethyl-3-(3-dimethylaminopropyl) carbodiimide $\mathrm{HCl}$ (EDAC) and bovine serum albumin (BSA) (nacalai tesque, Kyoto, Japan); normal rabbit serum (NRS) and $\mathrm{IgG}$ fraction of anti-rabbit $\operatorname{IgG}$ antiserum (second antibody) (Eiken Immunochemical Institute, Tokyo, Japan); Sephadex G-25 ${ }^{\circledR}$ fine (Pharmacia Biotech, Uppsala, Sweden); Freund's complete adjuvant (Difco Laboratories, Detroit, MI, U.S.A.); alkaline phosphatase (ALP, EC 3.1.3.1.) from calf intestine, arylsulfatase (EC 3.1.6.1.) from Helix pomatia (Boehringer Mannheim, Mannheim, Germany); a kit for measuring the activity of ALP "Alkaline Phospha K-Test ${ }^{\mathbb{B}}$ " (Wako Pure Chemical Industry, Osaka, Japan); Sep-Pak Vac $\mathrm{tC} 18^{\circledR}$ (disposable octadecyl silane cartridge, $500 \mathrm{mg}$ ) and Accell Plus QMA $^{\circledR}$ (disposable quaternary methyl ammonium conjugated silica cartridge, $300 \mathrm{mg}$ ) (Waters Corp., Milford, MA, U.S.A.). Steroid-free serum was prepared according to a method described by Heyns et al. ${ }^{15}$ Water was purified with a Milli-Q system (Nippon Millipore Ltd., Tokyo, Japan) and all other chemicals were of analytical grade. As a buffer for EIA, $0.067 \mathrm{~m}$ phosphate buffer ( $\mathrm{pH}$ 7.4) containing $0.25 \%$ BSA was used.

Synthesis of 16-DHP-3-hemisuccinate Synthesis of 16DHP-3-hemisuccinate (16-DHP-3HS) from 16-DHP was carried out according to the method of Erlanger et al. ${ }^{16)} \mathrm{In}$ brief, a solution containing $0.3 \mathrm{~g}$ of 16-DHP and $0.191 \mathrm{~g}$ of succinic anhydride in $6 \mathrm{ml}$ of dry pyridine was refluxed for $4.5 \mathrm{~h}$. The reaction mixture was evaporated to dryness under 
reduced pressure. The semisolid residue was then dissolved in chloroform and washed three times with water. Next, the organic solution was dried over sodium sulfate and evaporated to dryness. The residue was then recrystallized twice from acetone. The MS and a ${ }^{1} \mathrm{H}-\mathrm{NMR}$ spectra of the resulting compound were measured by a Hitachi-4100 and a Varian VXR-500 (500 MHz), respectively.

HPLC Conditions HPLC was performed using a system (Waters) of 2 pumps (model 510), a UV detector (model 481 ) operating at $210 \mathrm{~nm}$, an autosampler (model 710B) and a Wakosil-II 5C18-HG column $(250 \times 4.6 \mathrm{~mm}$ i.d.). The separations were performed at $40^{\circ} \mathrm{C}$ and at a flow rate of $1 \mathrm{ml} / \mathrm{min}$ with an isocratic condition of water-methanol $(32: 68, \mathrm{v} / \mathrm{v})$.

Serum Samples Neonatal serum (27-31 weeks of gestation, age: $1 \mathrm{~d}$ after birth) and cord serum (umbilical vein) from healthy pregnant women at term (37-41 weeks of gestation) were used. Cases with delivery complications were excluded from the study. Healthy adult serum was collected from men and non-pregnant women. The samples were kept frozen at $-40{ }^{\circ} \mathrm{C}$ prior to assay.

Preparation of Immunogen for 16-DHP 16-DHP-3HS was conjugated to BSA by the mixed-anhydride method. ${ }^{16,17)}$ Briefly, $10 \mathrm{mg}$ of 16-DHP-3-HS was dissolved in a solution containing $0.2 \mathrm{ml}$ of dimethyl formamide (DMF) and $5 \mu \mathrm{l}$ of tri- $n$-butylamine, and the solution cooled to $10^{\circ} \mathrm{C}$. After the addition of $5 \mu \mathrm{l}$ of isobutyl chlorocarbonate, the solution was stirred at $4{ }^{\circ} \mathrm{C}$ for $20 \mathrm{~min}$. This solution was then added dropwise to a mixture containing $40 \mathrm{mg}$ of BSA in $1 \mathrm{ml}$ of distilled water, $0.1 \mathrm{ml}$ of $1 \mathrm{M} \mathrm{NaOH}$ and $1.2 \mathrm{ml}$ of DMF. After the reaction mixture was stirred at $4{ }^{\circ} \mathrm{C}$ for $4.5 \mathrm{~h}$, it was dialyzed with DMF-water (1.2/1, v/v) and then lyophilized.

Preparation of Anti-16-DHP Antiserum A $2 \mathrm{ml}$ saline solution containing $1 \mathrm{mg}$ of 16-DHP-3HS-BSA was emulsified with $2 \mathrm{ml}$ of Freund's complete adjuvant. The emulsion was given to the rabbits on the back in multiple $1 \mathrm{ml}$ injections subcutaneously. Japanese white rabbits (two males and one female), each weighing $2 \mathrm{~kg}$, were used for the immunization. Booster injections were given at 2 -week intervals using the same dosage as the first immunization. The antisera were obtained from the three rabbits 8 weeks after the first immunization. One of the three antisera, with a higher specificity and titer, was chosen for use in the present study. Before use, the antiserum was diluted $1: 102400$ with $0.067 \mathrm{M}$ phosphate buffer ( $\mathrm{pH} 7.4$ ) containing $0.25 \%$ BSA.

Preparation of ALP-labeled 16-DHP ALP-labeled 16DHP was prepared by a carbodiimide method. ${ }^{18)}$ A solution containing $1 \mathrm{mg}$ of 16 -DHP-3HS in $0.3 \mathrm{ml}$ of DMF was stirred with $1 \mathrm{mg}$ of EDAC at room temperature for $1 \mathrm{~h}$. This reaction mixture was then added dropwise with stirring to a mixture of $0.05 \mathrm{ml}$ of ALP $(10 \mathrm{mg} / \mathrm{ml})$ and $0.5 \mathrm{ml}$ of $0.05 \mathrm{M}$ phosphate buffer ( $\mathrm{pH} 8.0)$. The tube was allowed to stand at room temperature with gentle stirring for $3 \mathrm{~h}$. The resulting solution was then applied to a Sephadex G-25 fine column $(30 \times 1.2 \mathrm{~cm}$ i.d. $)$, and eluted with $0.067 \mathrm{M}$ phosphate buffer ( $\mathrm{pH}$ 7.4). The fractions containing ALP-labeled 16-DHP were collected and stored at $4{ }^{\circ} \mathrm{C} .{ }^{18)}$ Before use, the fractions were diluted 1:400 with $0.067 \mathrm{M}$ phosphate buffer ( $\mathrm{pH} 7.4$ ) containing $0.9 \%$ NRS and $0.25 \%$ BSA.

Preparation of Serum Standards The 16-DHP stock solution, $0.5 \mathrm{mg} / \mathrm{ml}(1.59 \mathrm{mmol} / \mathrm{l}$ in methanol) was serially diluted with methanol (16-DHP methanol standard) and $150 \mu \mathrm{l}$ of diluted solution containing varying amounts of 16DHP, $2.93 \mathrm{pg}-30 \mathrm{ng}(0.009-95.5 \mathrm{pmol})$ were placed in tubes. By evaporating the methanol, and subsequently adding steroid-free serum $(0.2 \mathrm{ml}), 16-\mathrm{DHP}$ serum standards with a concentration range $0.015-150 \mathrm{ng} / \mathrm{ml} \quad(0.05-478 \mathrm{nmol} / \mathrm{l})$ were obtained. These serum standards were treated in the same manner as described below for sample preparation.

Sample Preparation for EIA Extraction of 16-DHP from serum samples was carried out as reported previously. ${ }^{13)}$ Briefly, $0.2 \mathrm{ml}$ of serum sample or serum standard was extracted with $1 \mathrm{ml}$ of methanol, three times. The solvents obtained were then combined and evaporated under vacuum. The residue was first applied to a solid phase extraction column, Sep-Pak Vac $\mathrm{tC} 18^{\circledR}$ and the column washed with $4 \mathrm{ml}$ of water. An anion exchange column, Accell Plus $\mathrm{QMA}^{\circledR}$ column was then connected to the Sep-Pak Vac tC $18^{\circledR}$ outlet. From the top of the Sep-Pak Vac tC $18^{\circledR}, 6 \mathrm{ml}$ of $72 \%$ ethanol was passed through both of these columns. The unconjugated steroids were obtained in this eluate since negatively charged steroid sulfates and glucuronides remained bound to the Accell Plus QMA ${ }^{\circledR}$ whereas the neutral steroids passed through. If necessary, the Sep-Pak Vac $\mathrm{tC} 18^{\circledR}$ was removed from the Accell Plus QMA ${ }^{\circledR}$, and then $6 \mathrm{ml}$ of $0.3 \mathrm{M}$ acetic acid in $72 \%$ ethanol was passed through the Accell Plus $\mathrm{QMA}^{\circledR}$ to exclude steroid glucuronides. Mono-conjugated sulfates such as 16-DHPS were then eluted from this column with $3 \mathrm{ml}$ of $0.3 \mathrm{M}$ acetate-sodium acetate buffer $(\mathrm{pH}$ 6.3 ) in $72 \%$ ethanol.

The unconjugated fraction was evaporated in vacuo. The residue was then dissolved in $0.3 \mathrm{ml}$ of the HPLC mobile phase, water-methanol $(32: 68, \mathrm{v} / \mathrm{v})$, and $0.25 \mathrm{ml}$ of the sample injected to the HPLC. The eluate collected between 22.5 and $25.5 \mathrm{~min}$ (retention time of 16-DHP, $23.8 \mathrm{~min}$ ) was the 16-DHP fraction. The solvent was evaporated under vacuum and the residue dissolved in $0.25 \mathrm{ml}$ of methanol. Aliquots of this solution $(0.1 \mathrm{ml})$ were transferred to duplicate tubes. After evaporation of the solvent, the residue was submitted to the EIA.

To investigate the correlation between the 16-DHP levels obtained using the present EIA and GC-MS, 16-DHPS was isolated from the mono-conjugated sulfate fraction which eluted from the Accell Plus QMA ${ }^{\circledR}$. The recovered sulfate was then treated with arylsulfatase to liberate unconjugated 16-DHP, ${ }^{13)}$ which was then further purified by HPLC using the same method as described above.

EIA of 16-DHP To each assay tube prepared as stated in the above section, $0.5 \mathrm{ml}$ of diluted anti-16-DHP antiserum and $0.1 \mathrm{ml}$ of diluted ALP-labeled 16-DHP were successively added (each dilution factor was mentioned in the above section). The mixture was then allowed to stand at room temperature for $1 \mathrm{~h}$, before $0.1 \mathrm{ml}$ of $3 \%$ second antibody in $0.067 \mathrm{M}$ phosphate buffer ( $\mathrm{pH} 7.4$ ) containing $0.25 \%$ BSA was added and the tube incubated at $4{ }^{\circ} \mathrm{C}$ overnight. Next, $2 \mathrm{ml}$ of water was added to the assay tube, and the reaction mixture centrifuged $(1000 \times \boldsymbol{g})$ at $4{ }^{\circ} \mathrm{C}$ for $50 \mathrm{~min}$. The supernatant was then aspirated and the subsequent precipitate washed again with $2 \mathrm{ml}$ of water. Finally, the enzyme activity of the resulting precipitate was measured with the Alkaline Phospha KTest $^{\mathbb{B}}$. A calibration curve was fitted by the quadratic logit$\log$ equation. ${ }^{19)}$ The program for the curve fitting was kindly 
provided by Dr. K. Ichihara of Kawasaki Medical School.

\section{RESULTS}

Synthesis of 16-DHP-3HS 16-DHP-3HS was synthesized as a ligand for conjugation with BSA and ALP. The product yield was $65 \%$. In the ${ }^{1} \mathrm{H}-\mathrm{NMR}$ spectra, the signal at $\delta 4.66(\mathrm{H}-3 \alpha)$ for the obtained compound appeared at a lower field than the signal at $\delta 3.52(\mathrm{H}-3 \alpha)$ for the starting compound (16-DHP). Furthermore, a multiplet at $\delta 2.59$ $2.71\left(\mathrm{CO}\left(\mathrm{CH}_{2}\right)_{2}\right)$ in the succinate moiety appeared. Detailed spectral data were as follows: ${ }^{1} \mathrm{H}-\mathrm{NMR}\left(500 \mathrm{MHz}, \mathrm{CDCl}_{3}-\right.$ $\mathrm{CD}_{3} \mathrm{OD}$, tetramethylsilane was used as the internal reference) $\delta: 6.71(1 \mathrm{H}, \mathrm{dd}, J=2,1.5 \mathrm{~Hz}, 16-\mathrm{H}), 5.39(1 \mathrm{H}, \mathrm{d}, J=5 \mathrm{~Hz}, 6-$ $\mathrm{H}), 4.66(1 \mathrm{H}, \mathrm{m}, 3-\mathrm{H}), 2.59-2.71\left(4 \mathrm{H}, \mathrm{m}, 3-\mathrm{OCO}\left(\mathrm{CH}_{2}\right)_{2}-\right)$, $2.26\left(3 \mathrm{H}, \mathrm{s}, 21-\mathrm{CH}_{3}\right), 1.06\left(3 \mathrm{H}, \mathrm{s}, 10-\mathrm{CH}_{3}\right), 0.92(3 \mathrm{H}, \mathrm{s}, 13-$ $\mathrm{CH}_{3}$ ). High-resolution CI-MS: Calcd for $\mathrm{C}_{25} \mathrm{H}_{35} \mathrm{O}_{5}[\mathrm{M}+\mathrm{H}]^{+}$: 415. 2484. Found: 415.2499.

Specificity of Antibody Percent cross-reactivities of the anti-16-DHP antiserum used are summarized in Table 1. The percent cross-reaction was calculated as follows: If $x=$ picogram of 16 -DHP required to displace $50 \%$ of ALP-labeled 16-DHP bound to the antibody and $y=$ picogram of steroid tested required to displace $50 \%$ of ALP-labeled 16DHP bound to the antibody, then the percent cross-reaction of steroid tested $=(x / y) \times 100$.

Standard Curve A typical standard curve is shown in Fig. 1. The minimal detectable amount of 16-DHP was $4 \mathrm{pg}$ $(0.013 \mathrm{pmol}) /$ assay. This value was determined from the $16-$ DHP concentration of -2 standard deviation at the 0 concentration of 16-DHP $(n=5)$. The measurable range of serum 16-DHP was $0.06-60 \mathrm{ng} / \mathrm{ml}(0.191-191 \mathrm{nmol} / \mathrm{l})$.

A standard curve (Curve I) obtained using the 16-DHP methanol standard without the addition of steroid-free serum according to the same procedure as that for the serum standards was compared with the one (Curve II) obtained using the same 16-DHP methanol standard (without serum), but with no purification steps i.e. without the Sep-Pak Vac $\mathrm{tC} 18^{\circledR}$ and Accell Plus QMA ${ }^{\circledR}$ columns, and HPLC. These two standard curves were superimposable in the 16-DHP concentration range over $2.34 \mathrm{ng} / \mathrm{ml}$. However, below the $2.34 \mathrm{ng} / \mathrm{ml}$ range, there was estrangement between the two curves (data not shown). This could be due to the 16-DHP being lost from the lower level containing standards during the purification step (Curve I). At a 16-DHP concentration of $1 \mathrm{ng} / \mathrm{ml}$, the percentage of loss was about $95 \%$.

Accuracy and Precision The accuracy was estimated from the recovery study. Various amounts of authentic 16DHP were added to $0.2 \mathrm{ml}$ of pooled umbilical cord serum (original concentration: 0.10 and $0.14 \mathrm{ng} / \mathrm{ml}$ ). The recoveries were $94.4 \pm 5.1 \%$ (mean \pm S.D., $n=4$, final concentration calculated: $0.29 \mathrm{ng} / \mathrm{ml}), 96.2 \pm 3.9 \%(3.80 \mathrm{ng} / \mathrm{ml}), 96.8 \pm 4.2 \%$ $(4.35 \mathrm{ng} / \mathrm{ml}), \quad 96.8 \pm 1.7 \% \quad(5.95 \mathrm{ng} / \mathrm{ml})$, and $95.2 \pm 5.7 \%$ $(16.3 \mathrm{ng} / \mathrm{ml})$, respectively. The intra-assay coefficient of variation (C.V.) was $4.1 \%$ at a concentration of $0.73 \pm 0.03 \mathrm{ng} / \mathrm{ml}$ $(n=6)$ and the value for the inter-assay C.V. was $7.7 \%$ at a concentration of $0.13 \pm 0.01 \mathrm{ng} / \mathrm{ml}(n=6)$.

Serum Dilution Study Three serum samples were serially diluted with steroid-free serum and their 16-DHP levels determined by the present EIA. As the result shows, a linear line, which passed through the zero point, was obtained be-
Table 1. Percent Cross-Reactivity of the Anti-16-DHP Antiserum Used in the Present Study

\begin{tabular}{lc}
\hline \multicolumn{1}{c}{ Steroids } & \% Cross-reactivity (50\%) \\
\hline 16-DHP & 100 \\
16-Dehydroprogesterone & 100 \\
16-DHP sulfate & 16.0 \\
16-OH-pregnenolone & 1.61 \\
Progesterone & 1.13 \\
Pregnenolone & 0.26 \\
Pregnenolone sulfate & 0.0022 \\
Dehydroepiandrosterone (DHEA) & 0.0020 \\
11-Deoxycorticosterone & 0.0016 \\
DHEA sulfate & 0.0012 \\
Testosterone & 0.0012 \\
Cortisol & $<0.001$ \\
11-Deoxycortisol & $<0.001$ \\
17-OH-pregnenolone & $<0.001$ \\
Androstenediol & $<0.001$ \\
16-OH-DHEA & $<0.001$ \\
Estrone & $<0.001$ \\
Estradiol & $<0.001$ \\
Estriol & $<0.001$ \\
Estriol 16-glucuronide & $<0.001$
\end{tabular}

The percent cross-reaction was calculated as follows: If $x=$ picogram of $16-\mathrm{DHP}$ required to displace $50 \%$ of ALP-labeled 16-DHP bound to the antibody and $y=$ picogram of steroid tested required to displace $50 \%$ of ALP-labeled 16-DHP bound to the antibody, then the percent cross-reaction of steroid tested $=(x / y) \times 100$.

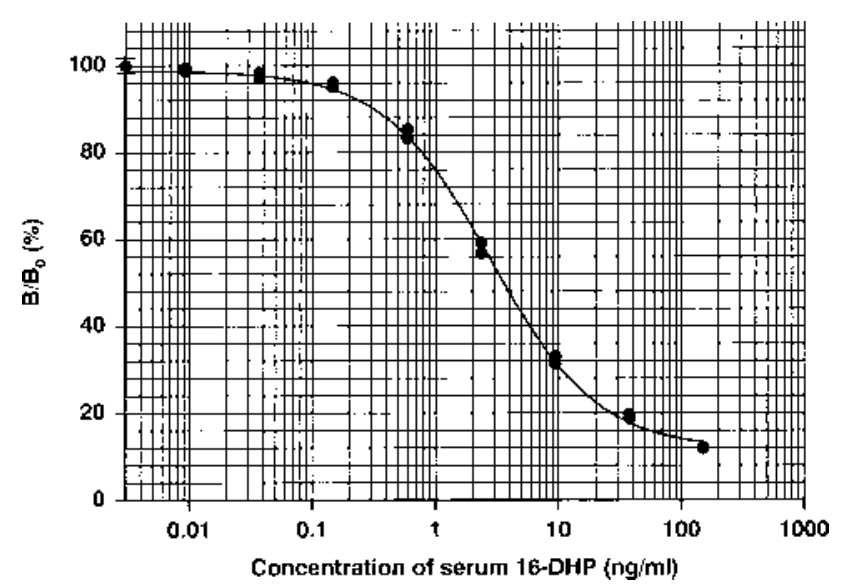

Fig. 1. Calibration Curve for the Enzyme Immunoassay of Serum 16-DHP

Calibration curve was obtained by plotting the $\mathrm{B} / \mathrm{B}_{0}(\%)$ versus the 16-DHP concentration on a logarithmic scale. Error bar at $0 \mathrm{ng} / \mathrm{ml}(n=5)$ indicates mean \pm 2 S.D. Each assay point was performed in duplicate.

tween the dilution and the 16-DHP concentrations for each sample (Fig. 2).

Comparison of 16-DHPS Values Obtained by EIA and GC-MS To investigate the reliability of the present EIA, the values measured were compared with those obtained by GCMS. The 16-DHP concentration in serum could not be measured by GC-MS due to its lack of sensitivity. Therefore, the 16-DHP levels were measured by both methods after enzymatic hydrolysis of the conjugated steroid, 16-DHPS. The 16DHPS levels of 27 cord (umbilical vein) serum samples from healthy pregnant women at term (weeks of pregnancy: 3741 weeks) were determined by GC-MS ${ }^{13)}$ and the proposed EIA. The samples for EIA, which were purified by HPLC after enzymatic hydrolysis, were diluted 800 -fold with methanol. As shown in Fig. 3, there was a good correlation be- 


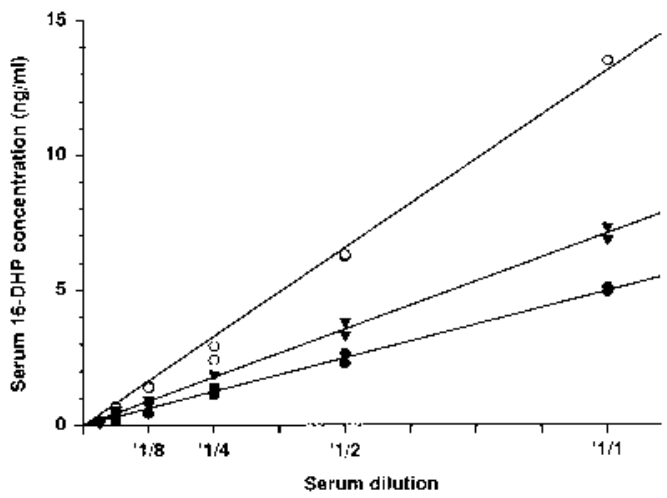

Fig. 2. Serum Dilution Study

Three serum samples were serially diluted with steroid-free serum.

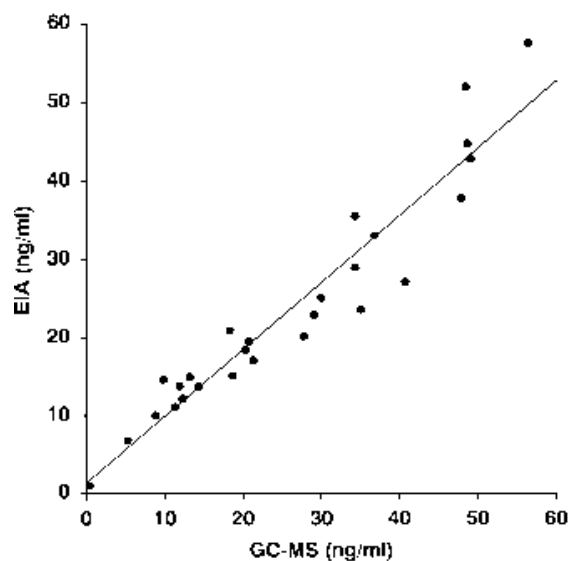

Fig. 3. Correlation between 16-DHPS Concentrations Obtained by the Proposed EIA and by GC-MS ${ }^{13)}$

Samples consisted of 27 cord (umbilical vein) sera obtained from healthy pregnant women at term (weeks of pregnancy: $37-41$ weeks). The distributions of 16-DHPS by GC-MS and the present EIA were shown to fit the normal distribution using the $\chi^{2}$-test, and therefore, a linear correlation of the 16-DHPS levels obtained by GC-MS and EIA were analyzed.

tween the values obtained by the two methods (Pearson's correlation efficient: $r=0.927, p<0.001, y=0.74 x+3.61, n=27$ ).

Concentrations of 16-DHP in Cord and Adult Serum Concentrations of 16-DHP in neonatal serum (27-31 weeks of gestation, age: $1 \mathrm{~d}$ after birth, $n=6)$, umbilical vein serum from pregnant women delivered at term (38.6 \pm 1.3 weeks of gestation, $n=18$ ) and serum from normal healthy adults (age $21-27$ years, male/female 4/12) were measured by the present EIA. Serum 16-DHP levels in the neonate and umbilical vein were $0.53 \pm 0.09 \mathrm{ng} / \mathrm{ml}$ and $0.88 \pm 0.61 \mathrm{ng} / \mathrm{ml}$, respectively. However, no 16-DHP was detected in any serum from the adults using the present EIA.

\section{DISCUSSION}

In 1994, we first identified 16-DHPS, which is a sulfate conjugate of 16-DHP, in the serum of immature infants. ${ }^{12}$ We also established a method for quantifying serum 16DHPS by GC-MS and have investigated 16-DHPS levels in the serum of neonates and maternal peripheral vein. ${ }^{13,14)}$ From these studies, it was found that this steroid originates from the fetus or neonates. We have also proposed the metabolic pathway for 16-DHPS as follows: Pregnenolone sul- fate $\rightarrow 16-\mathrm{OH}$-pregnenolone sulfate $\rightarrow 16-\mathrm{DHPS}$.

However, little is known about the unconjugated form, 16DHP. This is due to the low levels of this steroid in human circulation. To elucidate the physiological significance of unconjugated 16-DHP in the fetus or infant, we have established a sensitive EIA for this steroid using a newly prepared antibody raised against 16-DHP-HS-BSA in rabbit and ALPlabeled 16-DHP.

As shown in Table 1, the anti-16-DHP antibody used was relatively specific for 16-DHP, although the cross-reactivity for 16-dehydroprogesterone, 16-DHPS, 16-OH-pregnenolone and progesterone were $100,16,1.61$, and $1.13 \%$, respectively. Therefore, in order to purify the 16-DHP we applied the samples to solid phase extraction columns (Sep-Pak Vac tC $18^{\circledR}$ and Accell Plus QMA $\left.{ }^{\circledR}\right)$ followed by HPLC. The EIA was then performed on the 16-DHP fraction. Under these conditions, cross-reactive substances such as 16-dehydroprogesterone, 16-DHPS, 16-OH-pregnenolone and progesterone were excluded. Although the present EIA is a so-called bridge homologous competitive EIA, a sensitivity sufficient to measure the concentration of 16-DHP in serum samples was obtained. The present EIA also satisfied the standard criteria of dilution, accuracy and precision.

To investigate the reliability of the present EIA, the values were compared with those obtained by GC-MS. However, due to the low sensitivity of GC-MS, the concentrations of 16-DHP obtained after the enzymatic hydrolysis of 16-DHPS were determined by GC-MS and the present EIA. The values obtained by EIA were significantly correlated with those by GC-MS $(r=0.927, p<0.001)$.

During the purification of the 16-DHP methanol standards on the Sep-Pak Vac tC18 ${ }^{\circledR}$ and Accell Plus QMA ${ }^{\circledR}$ columns, and together with HPLC we observed a loss of 16-DHP from the lower concentration standards. Thus, the serum standards were processed by the same procedure including the purification steps as for the serum samples.

The present EIA next was applied to investigate the origin of 16-DHP. Serum 16-DHP levels in neonates, umbilical vein from pregnant women delivered at term and normal healthy adults were measured. The serum 16-DHP level in umbilical vein was significantly higher than that in neonates. However, no serum 16-DHP was detected in any normal adult with the present EIA. These findings suggest that 16-DHP as well as 16-DHPS originates from the fetus and neonate.

Further studies on the metabolic fate and physiological significance of 16-DHP in the fetus and neonate are now underway in our laboratory.

Acknowledgments This study was supported, in part, by Grants-in-Aid for Scientific Research from the Ministry of Education, Culture, Sports, Science and Technology of Japan and the Science Research Promotion Fund of the Japan Private School Promotion Foundation.

\section{REFERENCES}

1) Kwan T., Taylor N., Watson D., Gower D., FEBS Lett., 174, 173-178 (1984).

2) Watkins W. E., Glass T. L., J. Steroid Biochem. Mol. Biol., 38, 257263 (1991).

3) Gustafsson J.-Å., Shackleton C. H. L., Sjövall J., Eur. J. Biochem., 10, 302-311 (1969). 
4) Smith S. W., Axelrod L. R., Steroids, 15, $421-432$ (1970).

5) Shackleton C. H. L., Gustafsson J.-Å., Sjövall J., Steroids, 17, 265280 (1971).

6) Brandstrup N. E., Treiber L. R., J. Steroid Biochem., 2, 133-139 (1971).

7) Gustafsson J.-Å., Lisboa B. P., Steroidologia, 2, 27-37 (1971).

8) Schindler A. E., Wuchter J., Biol. Neonate, 27, 192-207 (1975).

9) Huhtaniemi I., J. Endocrinol., 59, 503-510 (1973).

10) Gustafsson J.-Å., Stenberg Å., Eur. J. Biochem., 22, 246-256 (1971).

11) Huhtaniemi I., Acta Endocrinol., 76, 525-538 (1974).

12) Kobayashi Y., Tagawa N., Saiki K., Watanabe F., Biol. Pharm. Bull., 17, 1501-1504 (1994).

13) Tagawa N., Nakata Y., Kusuda S., Kobayashi Y., Watanabe F., Biol.
Pharm. Bull., 20, 76-78 (1997).

14) Tagawa N., Kusuda S., Kobayashi Y., Biol. Pharm. Bull., 22, $1262-$ 1265 (1999).

15) Heyns W., Baelen H., Moor P. D., Clin. Chim. Acta, 18, 361-370 (1967).

16) Erlanger B., Borek F., Beiser S., Lieberman S., J. Biol. Chem., 234, 1090-1094 (1959).

17) Erlanger B., Borek F., Beiser S., Lieberman S., J. Biol. Chem., 228, $713-727$ (1957).

18) Nishiguchi Y., Kobayashi Y., Tagawa N., Miyai K., Watanabe F., Steroids, 57, 178-182 (1992).

19) Ichihara K., Yamamoto Y., Kumahara Y., Miyai K., Clin. Chim. Acta, 79, 331-340 (1977). 